\title{
The Contested Appropriation of George Gervase's Martyrdom: European Religious Patronage and the Controversy over the Oath of Allegiance
}

\author{
James E. Kelly
}

\begin{abstract}
From the beginning of the seventeenth century, Englishmen professed as Benedictine monks in mainland Europe began returning to their homeland. Until that point, the Catholic mission to England had been run by secular clergy and Jesuits, relationships between the two clerical parties growing increasingly troubled over how the Catholic Reformation should be implemented in England. The arrival of the Benedictines saw the offering of a "third way" to England's proscribed Catholics. Yet with the various missions dependent on lay Catholic resources and support both in England and in mainland Europe, it was necessary for the Benedictines to justify their presence in this often fraught environment. As such, they forcefully laid claim to contemporary English Benedictine martyrs against rival claims by other clerical groups. These battles for validation reached a new level of intensity following James I's serving of the Oath of Allegiance. This article explores how competing groups of English missionary clergy sought to justify their presence in England. Taking the case of two conflicting images of the executed George Gervase, it argues that the contest for martyrs sheds new light on the ways in which martyrdom was exploited by different groups; it also contributes to debates about the Oath of Allegiance, which was threatening to derail the wider Catholic Reformation across mainland Europe. By placing these clashes over English religious identity in both domestic and international contexts, the article makes evident that events on the peripheries of mainland Europe affected discussions at its center.
\end{abstract}

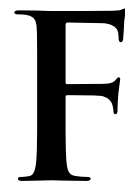

rom the beginning of the seventeenth century, Englishmen professed as Benedictine monks in mainland Europe began to return to their homeland. Until that point, the Catholic mission to England had been run by secular clergy and Jesuits, relationships between the two clerical parties growing increasingly troubled over how the Catholic Reformation should be implemented in England. The arrival of the Benedictines promised a "third way" to England's proscribed Catholics at a time when they were being served with a new Oath of Allegiance. Yet with the various missions dependent on lay Catholic resources and support both in England and in mainland Europe, it was necessary for the Benedictines to justify their presence in this often-fraught environment. Conscious of the Catholic

James E. Kelly is Sweeting Research Fellow in the History of Catholicism at Durham University. He thanks John McCafferty and Michael Questier for their comments on an earlier draft of this article and the journal's anonymous peer reviewers for their valuable advice. This work was supported by the Arts and Humanities Research Council (grant number AH/M003620/1). 
Church's official rejection of the Oath of Allegiance, the monks forcefully advertised contemporary English Benedictine martyrs, one of them the Catholic cleric George Gervase, executed in 1608. With different clerical factions claiming the martyrs as their own, these battles to secure validation from Catholic Europe were played out through a visual culture of commemoration. This article explores how competing groups of English missionary clergy sought to justify their presence in England and their vision of the Catholic Reformation. The contest over martyrs - in this case, George Gervase-sheds light on the ways in which martyrdom was exploited by distinct groupings and the fluidity of clerical identities on the peripheries of Catholic Europe.

Taken in isolation, the surviving archival material relating to Gervase's execution appears similar to other martyrological sources, apart from an apparent misunderstanding about his clerical status. However, in recontextualizing his martyrdom and its aftermath, this article shows that the sources have far wider ramifications, implicating religious identity, the character of the Catholic Reformation in England, and the fluidity of clerical groups. The sources reveal the religious identity of a faction of the wider English church.

Historians of early modern England, and particularly historians of the Puritans, have rightly recognized that not all Protestants can be grouped together as believing the same thing. Debora Shuger has observed that the post-Reformation English church was not made up of a simple binary split between Calvinists and cryptoCatholics; she stresses the necessity of a nuanced approach to "Protestantism," or at least conformity, in all its shades. ${ }^{1}$ Similarly, Alec Ryrie has encouraged the rediscovery of what he terms the "Protestant ecosystem," arguing against the tidy compartmentalization of Protestantism into Calvinism, Lutheranism, and a few rabid radicals on the side. He also highlights the plurality and diversity within the overarching category of Protestantism. ${ }^{2}$

However, the variety of positions within English Catholicism is rarely acknowledged. Apart from discrediting the notion that only recusants counted as Catholics and replacing it with the idea that a significant group opted for church papistry or occasional conformity, ${ }^{3}$ scholars still generally discuss early modern English Catholics as one homogenous group. Yet concerns about orthodoxy and self-definition were as relevant for early modern English Catholics as they were for the various Protestant factions of the nation. Peter Lake and David Como have addressed the topic of intra-Puritan debate in London, exploring it in terms of working out an orthodoxy, or at least setting the parameters of what it meant to be a Puritan. The very same process was alive in English Catholicism, the terms that Lake and Como use as applicable to Catholics as to the Godly: Catholics were as much an "underground" as

\footnotetext{
${ }^{1}$ Debora Shuger, "A Protesting Catholic Puritan in Elizabethan England," Journal of British Studies 48, no. 3 (July 2009): 587-630.

2 Alec Ryrie, "Protestantism' as a Historical Category," Transactions of the Royal Historical Society 26 (December 2016): 59-77. See also Peter Lake, "Calvinism and the English Church, 1570-1635," Past and Present 114, no. 1 (February 1987): 32-76; Peter Lake and Michael Questier, eds., Conformity and Orthodoxy in the English Church, c. 1560-1660 (Woodbridge, 2000), esp. David Como, "Puritans, Predestination and the Construction of Orthodoxy in Early Seventeenth-Century England," 64-87.

${ }^{3}$ On the issue of occasional conformity and Catholicism, see Alexandra Walsham, Church Papists: Catholicism, Conformity and Confessional Polemic in Early Modern England (Woodbridge, 1993); Walsham, Catholic Reformation in Protestant Britain (Farnham, 2014), 53-125.
} 
Puritans, if not more so. Lake and Como describe this "Puritan underground" as "a world of interministerial dispute and rivalry, of lay activism." They analyze "an overlapping series of networks of orally transmitted rumors and stories, of manuscript tracts" in which "the reputations of the Puritan clergy were made and maintained, and the nature of orthodoxy debated and defined through mechanisms and exchanges that remain, for the most part, closed to us"-or at least remained closed until the "underground" became the "public sphere," with the publication and wider dissemination of these disputes in particular circumstances. ${ }^{4}$ All these features of diversity and plurality can equally be ascribed to early modern English Catholicism. By considering the martyrdom of George Gervase and the conflicting reports circulated by different Catholic factions after his death, it is possible to see the same debates about orthodoxy and conformity to certain norms playing out in English Catholic circles.

Any attempt to group or dichotomize these individuals in order to count and evaluate them is thus risky, as contemporaries acknowledged. Even when English Catholic clergy began their training in continental colleges, religious identity remained changeable, and it was not clear what would be the end result. Hence there were continuing squabbles over Jesuits allegedly creaming off the best students or quarrels over Jesuit votive brethren who were ordained as secular clerics but had made a secret vow to join the society at an appropriate time in the future; hence also anger at the creation of Benedictine oblates, who trained as seculars but secretly aligned themselves with the monks. When these men returned to England, attempts to categorize them remained tricky, as in the cases of Robert Drury and George Gervase discussed here. They became a source of concern in their home country to the nation, as well as the English Catholic community, because of what they said, argued, and represented. This was particularly the case during major episodes such as the introduction of the Oath of Allegiance, when James I sought to engage with both Catholics and Protestants, to whom he wished to look tough on popery, tough on the causes of popery. Equally, what these individuals did was a matter of interest and concern not only to the English Catholic diaspora but to the whole enterprise of the Catholic Reformation, which the Oath was threatening to derail across mainland Europe. In such a climate, it is not surprising that religious identities became contested. Moreover, the reputation of Gervase the cleric was fought over by networks that were not only active in England but crossed the Channel. These networks reached across Catholic Europe as it sought to define and shape itself following the Tridentine reforms of the sixteenth century. In terms of religious identities, categories were not fixed, and what it meant to be "Catholic" was disputed, particularly in the wake of the Catholic Reformation.

It is therefore evident that Gervase's martyrdom and its appropriation was not an exclusively English issue; the images and documents produced were compiled in mainland Europe and circulated for a continental audience. As such, this article continues John Bossy's exploration of the implementation of the Catholic Reformation in England. Or, to put it another way, it focuses on the overarching question he

\footnotetext{
${ }^{4}$ Peter Lake and David Como, "'Orthodoxy' and Its Discontents: Dispute Settlement and the Production of 'Consensus' in the London (Puritan) 'Underground," Journal of British Studies 39, no. 1 (January 2000): $34-70$.
} 
identified as most pressing for contemporaries: should the English Catholic community be governed by the disciplinary decrees of the Council of Trent? ${ }^{5}$ England's adherents to Rome were dealing with questions not faced by their contemporaries in Catholic countries in mainland Europe, where a church hierarchy was in place to deal with such matters. In these circumstances, even a question of how to classify an individual like Gervase became a matter of some difficulty, and the dispute over "ownership" of his martyrdom a result of these contested identities.

The Gervase case contributes to wider debates about the relationship between center (or centers) and peripheries in the process of Catholic reform. As Tadhg Ó hAnnracháin has noted, Catholic reform shaped itself in response to contemporary conditions and, on the peripheries, was willing to adopt a pragmatic approach to achieve its non-flexible theological goals. ${ }^{6}$ The peripheries of Catholic Europe could prove to be a test of the Catholic Reformation experiment, exposing points of debate as it rubbed up against the confessionalized Protestant state. While this article is therefore about the Catholic Reformation in England, it is also about the wider Catholic reform movement. The Gervase episode brings to light how issues on the peripheries could affect debates in the center on issues such as allegiance and the relation between temporal and spiritual sovereignty. Equally, this phenomenon of "accommodation and (selective) appropriation," in the words of Simon Ditchfield, ${ }^{7}$ shows the English experience as relevant to historiographical movements focused on decentering the Catholic Reformation. England was part of the wider, even global, Catholic Reformation, and how it was to be implemented in the country was a matter up for debate, as witnessed by the events outlined in this article.

\section{THE MARTYRDOM OF GEORGE GERVASE}

A story circulating about the young George Gervase, who had been born at Bosham, Sussex, in 1569, claimed that he had been kidnapped by pirates and spent a formative twelve years under their tutelage. ${ }^{8}$ The truth of the tale depends on one's point of view: Gervase was part of Sir Francis Drake's final voyage to the Indies in 1595, as he himself attested. ${ }^{9}$ Following that adventure, he traveled to the English College at Douai, France, the exile institution devoted to training young English Catholic men for the priesthood. Ordained on 1 June 1603, he was sent to England the next year and was subsequently arrested and imprisoned in Durham and banished in 1606. After a brief visit to Rome, he returned to Douai and then once again made for his homeland in summer 1607. Captured a final time, he was

\footnotetext{
${ }^{5}$ John Bossy, The English Catholic Community, 1570-1850 (London, 1975), 27-29, 53-56, 136.

${ }^{6}$ Tadhg Ó hAnnracháin, Catholic Europe, 1592-1648: Centre and Peripheries (Oxford, 2015).

7 Simon Ditchfield, "Decentering the Catholic Reformation: Papacy and Peoples in the Early Modern World," Archiv für Reformationsgeschichte - Archive for Reformation History 101, no. 1 (October 2010): 186-208.

${ }^{8}$ Richard Challoner, Memoirs of Missionary Priests, ed. John H. Pollen (London, 1924), 294-96.

9 The National Archives (hereafter TNA), SP 14/19/2.I, "Examination of Geo. Jarvis, relative to his education, and where he abode and exercised his profession, since he came into England," 1 March 1606.
} 
hanged, drawn, and quartered at Tyburn, on 11 April 1608 in the Julian calendar, or on 21 April 1608 according to the Gregorian system of dating. ${ }^{10}$

An image of Gervase dressed as a member of the secular clergy was soon in circulation (figure 1). The Latin text around it explained that Gervase was a priest of the English College at Douai. The text maintained that, although condemned to death for being a seminary priest, he was actually executed for refusing to take the Oath of Allegiance "recently devised by the English Parliament, against the authority of the Supreme Pontiff and the Apostolic See." The writer then recorded that, for the same cause, two other alumni of the college, Matthew Flathers and William Mush, were executed in York around the same time. The text boasted that "thus have gone forth from this one College, in the renowned University of Douai, founded in the year 1568, ninety-seven martyrs.” For good measure, the writer ended by acknowledging that many from the Society of Jesus and the other exile colleges had also suffered "in England during the storm of persecution now raging." 1

The text allows for the dating of the broadsheet's creation. Though Bede Camm correctly pointed out that there was no martyr named William Mush, he mistakenly identified the cleric involved as John Mush. ${ }^{12}$ William Mush was in fact the younger brother of John, now best known for having been confessor to Margaret Clitherow and for writing an account of her martyrdom in York in 1586. ${ }^{13}$ The William Mush referred to was captured in Yorkshire in 1608 and condemned to death. Fortuitously, he managed to escape from York Castle, avoiding the gallows. ${ }^{14}$ However, news of his escape took time to reach his alma mater in mainland Europe; instead, the diary of Douai College recorded that he was martyred at the end of May 1608. A side addition corrected this original report, noting that the college's inhabitants received updated news that Mush was not martyred after all. Nevertheless, that they believed him dead at the end of May 1608 is the key point. ${ }^{15}$ By 2 August 1608 , copies of the pamphlet were already in circulation, ${ }^{16}$ meaning that, allowing time for printing and distribution, its production can be dated between the end of May and mid-July 1608. In other words, the broadsheet, vocal in its praise of the English College at Douai, was rushed into print to capitalize on the recent martyrdom of George Gervase.

However, this was not the only publication to be disseminated celebrating Gervase's martyrdom. Another image, this time depicting Gervase as a Benedictine

${ }^{10}$ E. H. Burton and T. L. Williams, eds., Donay College Diaries: Third Diary, 1598-1637, Catholic Record Society (hereafter CRS) 10 (London, 1911), 28, 50, 51, 60, 74, 84, 85, 90; Godfrey Anstruther, The Seminary Priests, vol. 2, Early Stuarts, 1603-1659 (Ware and Great Wakering, 1975), 128-29. All dates from this point are given according to the Gregorian calendar then in use in Catholic Europe, unless otherwise stated.

${ }^{11}$ Archivum Britannicum Societatis Iesu (hereafter ABSI), cause papers, George Gervase picture file. This is a photograph of an item reportedly held in the Vatican archives, but the reference given is incorrect, and despite searches in the Vatican's Library, Archives, and Secret Archives, the original cannot be located.

12 Translation from original Latin given in Bede Camm, Nine Martyr Monks: The Lives of the English Benedictine Martyrs Beatified in 1929 (London, 1931), 98-99.

${ }^{13}$ John Morris, ed., The Troubles of Our Catholic Forefathers, vol. 3 (London, 1877), 331-440.

${ }^{14}$ Godfrey Anstruther, The Seminary Priests, vol. 1, Elizabethan, 1558-1603 (Ware and Great Wakering, 1968), 242.

15 Burton and Williams, Donay College Diaries, 92, 352.

${ }^{16}$ See below, page 228 . 
monk (figure 2) and therefore openly contradicting the other, was also in circulation. ${ }^{17}$ The existence of these two conflicting images could be explained as a product of contemporary confusion over Gervase's clerical status. For example, the Spanish holy woman Luisa de Carvajal, who made it her business to be well acquainted with the vicissitudes of England's covert clergy, seemed oblivious to the fact that Gervase was a Benedictine. Writing on 23 April, shortly after his death, and several times on 29 June 1608, she consistently treated him as a secular cleric. ${ }^{18}$ Only four months after his death did she learn that "before he was imprisoned he had lived as a member of the order of St Benedict." ${ }^{\prime 19}$ Equally, the superior of the Jesuits, Richard Holtby, writing to Robert Persons, S.J., on 15 April 1608, the day after Gervase's sentencing, described him as "a Seminary pr ${ }^{t}$," only after the execution correctly referring to him as "a benedictin." 20 Such confusion was no doubt exacerbated by delays in the spread of news to those on the continent, not to mention the potential unreliability of some reports. ${ }^{21}$ Certainly, the Benedictine Augustine Baker seemed to experience such difficulties. Writing his "Treatise of the English Benedictine Mission” in 1635 at Saint Gregory's monastery in Douai, he initially described another monk, John Roberts (d.1610), as the protomartyr of the English Benedictine mission. Baker corrected himself in the next sentence: "Reflectinge more on this matter, I now remember that there was one of our order and missioner that suffred before him"-namely, Gervase. However, Baker believed Gervase had never been a member of a particular monastery and was received into the order "by our other Spanish fathers in England," meaning by an Englishman who had professed at a Spanish monastery. ${ }^{22}$ If a chronicler of Benedictine activity such as Baker could be confused by the details of Gervase's life, it is little wonder that others could experience similar uncertainty.

Nevertheless, in other quarters, there was evident certainty of Gervase's membership of the Benedictines. An eyewitness account written by Gervase's "ghostly Father," Robert Charnock, ${ }^{23}$ relates the initial questioning of Gervase after capture. Charnock recorded that Gervase admitted his priesthood and, when asked if he belonged to a religious order, replied, "Yea and of the order of $S^{t}$ Bennett." A contemporary hand has added to the text an extract from a letter sent from London in 1608: "F. Gervase both at the Barr[,] at his arraygnment and at his

\footnotetext{
17 "Varia de Rebus Angliae super successione ad Regnum variae relationes ab anno 1597 usq. ad 1608," Vatican Library, Vat.lat.6227, fol. 212rbis. My thanks to Maurice Whitehead for his assistance with the archives in Rome.

${ }^{18}$ Glyn Redworth, ed., The Letters of Luisa de Carvajal y Mendoza, trans. David McGrath and Redworth, 2 vols. (London, 2012), 1:300-8; $: 1-40$. It cannot be argued that Luisa was ignorant of the difference between religious and secular clerics: shortly after writing about Gervase, she says "a Benedictine monk," most likely John Roberts, was expected to be executed. Ibid., 2:22.

19 Ibid., 2:45.

${ }^{20}$ Richard Holtby to Robert Persons, 15 April 1608, Anglia, 37, fol. 330v, Archivum Romanum Societatis Iesu.

${ }^{21}$ For these issues, see News Networks in Early Modern Europe, ed. Joad Raymond and Noah Moxham (Leiden, 2016), esp. Raymond and Moxham, "News Networks in Early Modern Europe," 1-16.

${ }^{22}$ Ampleforth Abbey, MS 119, fol. 447 in Memorials of Father Augustine Baker and Other Documents Relating to the English Benedictines, ed. Justin McCann and Hugh Connolly, CRS 33 (London, 1933), 175.

${ }^{23}$ The account is signed "Ro Cha." The only alternative to Charnock is Robert Chambers, but he was chaplain to the English convent of Benedictine nuns at Brussels from 1599 to 1628 , so he is unlikely to have been an eyewitness to Gervase's martyrdom. Anstruther, Seminary Priests, 1:70, 73-75.
} 
death did declare himself to be a monk of St Benet order." 24 On the day of Gervase's execution, 21 April 1608, the Spanish envoy to England, Pedro de Zúñiga, wrote to Phillip III from London, describing Gervase as "a Benedictine monk." 25 An Italian account of the trial and martyrdom dated 23 April 1608 had Gervase declare himself a monk at the start of his trial, as well as at the moment the noose was placed around his neck, adding for good measure that he was a Benedictine "from whom England acknowledged that she had received the Christian faith." 26 In the month following Gervase's death, the secular cleric John Cecil informed the apostolic nuncio in Paris that Gervase had been executed in London and pronounced himself a Benedictine. ${ }^{27}$ In attempts by early secular clergy to launch a cause for canonization at Rome, even Richard Smith, the future bishop of Chalcedon and scourge of the religious orders, stated that Gervase openly professed himself a Benedictine monk when stood under the noose. ${ }^{28}$

As for Benedictine sources, Augustine Baker's final realization in his account of the English Benedictine mission was that Gervase, "comminge forth of the English colledge at Doway for goinge missioner to England, privily tooke the habit at the hands of father Augustine Bradshaw alias White in a part of the howse of Trinitarians at Doway, where our Spanish English fathers had then an hired habitation."29 Bradshaw himself wrote an account of Gervase's martyrdom in which he explicitly stated that he had received him into the order. ${ }^{30}$ In fact, Baker's uncharacteristic dithering appears even stranger when it is considered that Clement Reyner, in his Apostalatus Benedictinorum in Anglia ... (1626), was certain of Gervase's Benedictine character and his having been received into the order by Bradshaw. ${ }^{31}$

The explanation that the depiction of Gervase as a secular cleric rather than a Benedictine was an accident can therefore be dismissed: his membership of the order was recognized within days of his martyrdom and quickly accepted as fact. The image of Gervase as a secular was instead part of wider struggles about the contested identity of English Catholicism. A late seventeenth-century handwritten annotation on the

\footnotetext{
${ }^{24}$ Account of the martyrdom of George Gervase, A VIII, no. 52: 287, 289, Westminster Diocesan Archives (hereafter WDA).

${ }^{25}$ Sección de Estado, Legajos 2586/99, Archivo General de Simancas, nr. Valladolid, printed in Spain and the Jacobean Catholics, vol. 1, 1603-1612, ed. Albert J. Loomie, CRS 64 (London, 1973), 117-19.

26 TNA, Roman Transcripts (Bliss), 23 April 1608, translation from Italian in Camm, Nine Martyr Monks, 87, 95. Similarly, The Apprehension, Arraignment, and Execution of E. Abbot as Also the Arraignement, Conuiction, and Execution of George Iarmis Priest after the Order of Saint Benedicts, Both Which Suffered Death on Munday the Eleuenth of Aprill, 1608, was printed in London in 1608 (English Short Title Catalogue S1757). The section relevant to Gervase is not included in the Early English Books Online copy, and the British Library copy was destroyed during World War II. An Italian translation of the work exists at the Vatican Library, Vat.lat.6227, fols. 209r-212r.

${ }_{27}$ TNA, 31/9/116, fol. 11 (author's translation from the original Latin).

${ }^{28}$ Richard Smith, accounts of martyrs, A IX, no. 53: 291-92, WDA.

${ }^{29}$ Ampleforth Abbey MS 119, fol. 447, in McCann and Connolly, Memorials of Father Augustine Baker and Other Documents, 175.

${ }^{30}$ Anstruther, Seminary Priests, 2:129. Anstruther's reference is not correct; it should be Fondo Gesuitico 651, folder 617, Archivum Romanum Societatis Iesu. This folder has been missing for many years and remains so despite searches in the archive; nor is there a copy of it, even as a transcription, at ABSI.

${ }^{31}$ Clement Reyner, Apostalatus Benedictinorum in Anglia, siue, Disceptatio Historica, de antiquitate ordinis congregationisque monarchorum nigrorum S. Benedicti in regno Anglic (Douai, 1626), Tract I, 242, 247: Ushaw College Library, IX.D.5.10.
} 
pamphlet alleges that Thomas Worthington, then president of Douai College, was probably responsible for the attempt to appropriate Gervase as a secular cleric but offers no evidence to support this claim. ${ }^{32}$ Its accuracy can now be corroborated. On 2 August 1608, Thomas Fitzherbert, the English archpriest George Birkhead's agent in Rome, wrote to Worthington in Douai confirming that he had "receaved your letter with the printed pamphlets concerning the processe of that blessed martir, which I have distributed to some frends." That the pamphlet mentioned is that of Gervase as a secular cleric is confirmed by Fitzherbert's next comment: "I make no dout but it ys ill taken by the Benedictines with you, and so yt wilbe by theym here." Fitzherbert admitted that he believed the Benedictines had "secretly receaved" Gervase and was sure that he had resolved to join them when he left Rome during his banishment from England. Fitzherbert added that he had seen "relations from England that he confessed it at hys arraygnment, though the adversaryes mistook it, as it appeareth in the pamphlet." Still, Fitzherbert saw no reason to let truth get in the way of the pamphlet's public-relations exercise, concluding, "Nevertheles all that which you affirme in the annotation ys very true excepting, that which concerneth hys intention, though the reason which you geve, ys probable."33

Half a year later, on 7 March 1609, Fitzherbert again wrote to Worthington, informing him that all that Lorenzo Bianchetti, cardinal vice-protector of England, was hearing from the nuncio at Brussels, Guido Bentivoglio, was "that the quarrels betwixt you and theym [the Benedictines] have ben in great part about a martyr in England whom eyther of you challenge for yours." 34 A few months later, on 22 August 1609, Fitzherbert warned Worthington that a complaint had been received in Rome concerning "the blessed martir $\mathrm{M}^{\mathrm{r}}$ Gervase (as I take it), or some such other, as the benedctins do challenge for theyres whereof they say you published the contrary making him a secular priest." Fitzherbert said he thought it was no great concern, but he advised that if Cardinal Bianchetti directly enquired about the matter, it might be better for Worthington "to take no knowledge of it." 35 Such a denial would have required some casuitical flexibility on Worthington's behalf: as well as being responsible for the pamphlet, he certainly knew of Gervase's Benedictine credentials, as he had recognized them in a letter to the cardinal protector dated 17 May 1608. ${ }^{36}$

What was Worthington's motivation for portraying Gervase as a martyr of the secular clergy? Worthington himself identified one in the aforementioned letter, and it has some justification. He pointed out that Gervase had not undertaken his noviceship in a monastery, an argument resting on the tenets of the Council of

\footnotetext{
${ }^{32}$ ABSI, cause papers, George Gervase picture file. The note is in the hand of Christopher Grene, S.J., the seventeenth-century collector of materials relating to the English and Welsh martyrs. Grene writes, "This picture was in all likelyhood made by the Sem. of Douay"; he goes on to quote a letter of complaint about the Benedictines from Worthington. The image, along with the comment in Grene's hand, was evidently part of his second Collectanea volume on martyrdom that was dispersed. This is evidenced by Grene's reference to more Gervase material in "MII" and his instruction to consult volume 5; see ABSI, Collectanea, N II, 9.

${ }^{33}$ Leo Hicks, ed., Letters of Thomas Fitzherbert, 1608-1610, CRS 41 (London, 1948), 25-26.

${ }^{34}$ Ibid., 47.

35 Ibid., 55-56.

${ }^{36}$ Letter copied by Grene: ABSI, cause papers, George Gervase picture file.
} 
Trent. ${ }^{37} \mathrm{He}$ also observed the fledgling English Benedictine movement's tactic of receiving members secretly and in turn its policy of creating oblates, that is, clerics who affiliated themselves with the monks and promised to profess as one of their number at an opportune time. That the Benedictines were acting as accused is witnessed in the profession book of their priory, Saint Gregory's in Douai. The first entry is not actually of a profession but the vow of oblation offered by Joseph Haworth on 18 July 1607 promising to enter the order when Augustine Bradshaw declared it a suitable moment. ${ }^{38}$ Tellingly, Haworth had been dismissed with six others from Worthington's Douai College on 25 May 1607 for dealing with Bradshaw about joining the Benedictines. ${ }^{39}$ This practice of poaching ready-trained clerics was a continuing source of irritation for the secular clergy associated with the exile colleges; in the 1614 edition of his Catalogus Martyrum, Worthington bemoaned that the Benedictines "called to be oblates in England" some trained by the colleges. ${ }^{40} \mathrm{He}$ was not the only one to be agitated about the matter. On 9 April 1609, the secular cleric William Singleton wrote to a colleague, "You must understand that the benedictines in England receive, as they call them, many donates in England, and omit nothing to make themselves populous and a great multitude, imagining to do by numbers what they cannot by virtue." 41

The issue clearly vexed Worthington, and his own published writings displayed his sourness over the Gervase affair. In the first edition of his A Relation of Sixtene Martyrs, published in 1608 within months of Gervase's death, Worthington described him as a "Priest of Doway." As an addendum, Worthington disdainfully wrote, "Who, as some say, was secretly received into the holie Order of $S$ Benedict before his death. Not a Monke, for he never was Novice, but as Oblate, that is, one that offereth himself to that order, and is admitted to the privileges therof." 42 In the more detailed Latin edition of 1614, Worthington remarked caustically in a coda on Gervase that, when in Rome, the martyr had petitioned to join the Jesuits but was refused. For good measure, he added, "Shortly before his martyrdom he offered himself to St Benedict's order, and he was enrolled," thus giving the impression that the Benedictines would take anyone in comparison to the more selective Jesuits. ${ }^{43}$

\footnotetext{
${ }^{37}$ Canons and Decrees of the Council of Trent: Original Text with English Translation, trans. H. J. Schroeder (Rockford, 1978), 226.

${ }^{38}$ Downside Abbey, Liber Graduum, p. 1. Haworth would actually go on to profess as Joseph of Saint Mary at Saint Laurence's, Dieulouard on 8 September 1609, having taken the habit there on 1 August 1608. Others who made oblations of themselves include Augustine Lee, alias Johnson, who undertook his novitiate at Saint Gregory's in 1608, having been ordained at Seville College and oblated himself to Bradshaw, and Placid Hartburn, who made a solemn oblation of himself on the mission having been ordained at Douai College in 1609; ID 477, 522, Monks in Motion database, www.dur.ac.uk/mim, accessed 25 October 2017.

39 See below, pages 232-33.

${ }^{40}$ Thomas Worthington, Catalogus Martyrum pro Religione Catholica in Anglia Occisorum (1614), 8: Durham Palace Green Library, Routh 25.H.26.

${ }^{41}$ Mark A. Tierney, Dodd's Church History of England from the Commencement of the Sixteenth Century to the Revolution in 1688, 5 vols. (London, 1839-43), 4:ccxix.

${ }^{42}$ Thomas Worthington, A Catalogue of Martyrs in England, facsimile print of the copy at Oscott College in D. M. Rogers, ed., English Recusant Literature 1558-1640, vol. 363 (Ilkley, 1978), 23-24.

${ }^{43}$ Ibid., 49-50 (author's translations from the Latin). This story of Gervase seeking to join the Jesuits is not recorded anywhere else but is repeated by Richard Challoner, no doubt taking Worthington as his authority. Certainly, Worthington appears to be the source of the story, which Camm was unable to identify,
} 
The practice of creating oblates had a wider impact, in Gervase's case creating a sense of Benedictine sacrifice for the English mission that the likes of Worthington believed rightly belonged to the colleges. For example, an account of the martyrdom of the priest Robert Drury began circulating shortly after his execution on 26 February 1607. Though he was trained and eventually ordained at the English College in Valladolid, A True Report of the Arraignment, Tryall, Conviction, and Condemnation, of a Popish Priest, Named Robert Drewrie portrayed him as donning a Benedictine habit for his execution and described him as "drawn in his Priestly Habit, and as he was a Benedictine Fryer." The pamphlet's author referred to Drury as a priest and "fryer of the Benedictine order," who even wore the "Fryer-Benedictine Habbet" for the day of his execution, namely "a newe suit of aparrell, being made of black stuffe ... after the maner of the Benedictine fryers beyond the seas." Some papers discovered on Drury's person were exhibited to the crowd at Tyburn, including "his Benedictine faculty under seale, expressing what power and authority he had from the Pope, to make men, women, and children heere, of his order." 44 There is no record of Drury having entered the Benedictines, nor did the English monks ever try to claim him. Rather, it seems likely that he was an oblate or confrater and the faculty that was produced was the one allowing him, in turn, to receive oblates. Indeed, it was probably Drury who was referred to in a paper drawn up by Anselm Beech, O.S.B., and presented to the pope, stating that a confrater of the order had been martyred for refusing the Oath of Allegiance. Notably, the Jesuits also reportedly laid claim to Drury, saying he entered the Society two days before his execution, though the secular clergy forcefully rejected this. ${ }^{45}$

\section{THE ENGLISH CATHOLIC DIASPORA AND ENTERPRISE}

As irritating as Worthington found the Benedictines' activities, there were more significant reasons behind his decision to claim Gervase for the secular clergy cause. Particularly pertinent was the situation of the English College at Douai and Worthington's own position there. By 1598, the college was heavily in debt and had to contract new loans to meet expenses. A year later, in June 1599, Worthington became the college's third president, but his tenure started with a disastrous pontifical visit. The visitors' report was damning, citing insufficient funds to support the students, creditors chasing the college, a constant need to raise funds, resulting in lack of food and clothing for the students, and, finally, lax discipline. The cardinal

\footnotetext{
and in the context it seems that it was meant as defamatory. Camm, Nine Martyr Monks, 69; Challoner, Memoirs of Missionary Priests, 295.

${ }^{44}$ Printed in The Harleian Miscellany: A Collection of Scarce, Curious, and Entertaining Pamphlets and Tracts, as well in Manuscript as in Print, vol. 3 (London, 1809), 38, 40, 46-47: Ushaw College Library, X.E.4.11.

${ }^{45}$ Tierney, Dodd's Church History, 4:ccxiii; Anstruther, Seminary Priests, 1:104-5; Peter Holmes, s.v., "Drury, Robert (1567-1607)," in Oxford Dictionary of National Biography, ed. David Cannadine (Oxford, 2004), http://www.oxforddnb.com/view/article/8098, accessed 31 March 2017. Bede Camm ventures that Drury was received as an oblate by another Benedictine martyr, John Roberts, plus that Matthew Flathers, a graduate of Douai College who was executed at York on 21 March 1608, was also a Benedictine oblate. Camm, Nine Martyr Monks, 87-88, 129-30.
} 
protector of England, Odoardo Farnese, ordered a number of reforms and adopted Worthington's recommendation to install a Jesuit as ordinary confessor to the students. This move was disastrous, particularly in the heat of the Archpriest Controversy ${ }^{46}$ then engulfing English Catholicism both at home and abroad. The students of the college already viewed Worthington as close to the Jesuits and particularly to their bête noir Robert Persons, to whom Worthington had made a vow of obedience. In addition, they-and anti-Jesuit secular clergy in England-suspected Worthington wanted to give the college over to the Society's control. Moreover, Worthington was known to be out of sympathy with a significant faction of the secular clergy in the Archpriest Controversy, as he supported the Jesuit-inclined archpriest George Blackwell.

Dissatisfaction against Worthington grew, as he was accused of sacking old, wise professors for young "yes men" known to support the Jesuits. He was also accused of presenting barely trained students for ordination, embarrassing the English secular clergy's mission by sending a stream of incompetents to their homeland. The college president's situation became even more precarious with the appointment of a new archpriest following the shaming of Blackwell for having capitulated and taken the Oath of Allegiance after his capture in England. Blackwell's successor, appointed in 1608, was George Birkhead, a man who Worthington-like his Jesuit friends - could not initially support because he championed the appointment of a bishop to restore order among England's Catholics and represent them to the regime. Indeed, Birkhead's appointment occurred on 1 February 1608, only two months before the crisis point of Gervase's martyrdom. Less than a year later, Birkhead directly challenged Worthington over his financially and administratively calamitous management of the college. In other words, Worthington was left with no support in charge of a college on the brink of collapse, having compromised himself for having backed a figure who had been weak on the Oath of Allegiance.

These events came to a crisis point around the time of Gervase's death. One repercussion of Worthington's reportedly overseeing the production of poorly trained clergy was a damaged reputation for Douai in England. According to Dodd, lay Catholics "gradually closed their doors against every member of the clergy, with whom they were not personally acquainted." Exacerbating matters, Worthington "still continued to pour in his illiterate recruits," meaning that "month after month, fresh supplies of useless labourers arrived." 47 With competition already

\footnotetext{
${ }^{46}$ Also known as the Appellant Controversy, it involved an anti-Jesuit faction of the secular clergy appealing to Rome for the re-establishment of an English ecclesiastical hierarchy. The faction's aim was both to become the recognized voice of the nation's Catholic community and to curtail Jesuit influence and shape the community as they believed best. For an overview, see Bossy, English Catholic Community, 35-48; Thomas M. McCoog, S.J., "Recognising the Archpriest: Seeking Clarification or Formenting Schism?," British Catholic History 32, no. 4 (October 2015): 473-91.

${ }^{47}$ For summaries of the Worthington saga and the situation at Douai as outlined in this paragraph and the preceding, see Burton and Williams, Doway College Diaries, xvi-xviii; Tierney, Dodd's Church History, $5: 3-12$, iv-vi, ciii-cvi. It is worth noting that Dodd's account of the decline in seminary training standards is polemically charged, relying as it does on contemporary claims against Worthington, a man who appears to have possessed a character that could excite considerable hostility. Nevertheless, the college diaries, although more circumspect, attest that all was not right in the seminary. It is significant as well that contemporaries intent on dislodging Worthington from the presidency evidently felt they could make such claims without their being dismissed as outlandish.
} 
acute between the secular clergy and the Jesuits for English Catholic support-both to finance the exile colleges and also to provide missioners with a base and sustenance- the arrival of a fledgling Benedictine mission only aggravated the situation. A martyr like Gervase would help to raise the order's profile and justify its presence in England: hence Benedictine efforts to publicize him widely. Worthington also needed an attention-grabbing cause to steady his own presidency and restore the reputation of Douai and its missioner product. Thus, with a partially valid claim over Gervase, he made his move against the Benedictine challenge to the college's reputation and resources.

All this was happening precisely as the Benedictines were establishing their first specifically English house in Douai. In 1606 Augustine Bradshaw began what would become the community of Saint Gregory's in the immediate vicinity of the college at Douai. ${ }^{48}$ Worthington feared a repeat of events at the English College in Valladolid, which had seen a hemorrhaging of students from the college into the Spanish Benedictines. On 20 May 1607, Worthington and the college visitor, John Wright, dean of Courtrai, met to discuss ways of reducing student numbers in order to ease the college's financial distress. The pair fell upon seven students who they believed were intent on joining Bradshaw's monastic enterprise but were adhering to the monk's advice that it was fine to remain living in the college at the institution's expense. Worthington and his team accused the students of falsely taking the missionary oath and, moreover, of subverting "the discipline and observance of the house by their whisperings and mutterings; persuading others, as they have persuaded themselves, that they cannot become learned in this Academy, and that there is great hope of learning among the Benedictines." More pertinently, bearing in mind Worthington's agitation at Benedictine activities, the students' "manner of attaining" their goal was "not unjustly suspected, since it avoids the eye of the superior." 49 In the official Douai diary record, Worthington was portrayed as acting honorably, even if he had to be convinced to offer the seven expellees mealy-mouthed letters of commendation. However, the attempt to present the students as malcontents is suspect. The seven refused to leave, and on 1 June they appealed their expulsions directly to the rector of Douai University, whom Worthington haughtily dismissed: "In this affair he would not answer the Rector." On 15 June 1607, the last malcontent, Edward Nuttall, who the diary smears as feigning physical disability, was forcibly stripped of college dress. On this occasion, punches were exchanged. The others removed were Joseph Haworth, John Malone, Arthur Godfrey, George Field, Thomas Spicer, and Anthony Mann; four of the seven subsequently became Benedictines. ${ }^{50}$ Notably, Gervase returned to the college from Rome on 23 July, shortly after these events. No doubt dismayed at what he heard of these happenings, he kept his dealings with Bradshaw private. Tellingly, in a letter to the cardinal protector dated 17 May 1608, Worthington resurrected these accusations, taking umbrage with the Douai Benedictines for their duplicitous behavior in accepting

48 Tierney, Dodd's Church History, 4:88n2.

${ }^{49}$ Burton and Williams, Douay College Diaries, 80-83, 346-49.

${ }^{50}$ Ibid. Haworth entered the new community at Saint Laurence's, Dieulourd, on 1 August 1608, Nuttall following on 9 November 1609; Malone entered Saint Gregory's on 2 September 1608; Godfrey eventually professed at Monte Cassino on 10 January 1611. 
Gervase behind his back while he had been funding the martyr's mission in ignorance. ${ }^{51}$

As the expulsions were in progress, Worthington was busy working for the Benedictines' removal from Douai. On 20 January 1607, the papal nuncio in Brussels, Decio Caraffa, reported that Worthington had presented a petition to that effect. However, after initially being told to leave, the monks received important local support from the Abbot of Saint Vaast, Philippe de Caverel, and the bishop of Arras, Jean Richardot. As the dispute widened, Bradshaw and his Benedictine confreres sent Anselm Beech to lobby Rome against their opponents, including the Jesuits, who were by then calling for the suppression of the entire English Benedictine mission. By the late winter or early spring of 1608, the Jesuits had delivered their third anti-Benedictine memorial, and it looked as if the fledgling monastic community was doomed. However, in David Lunn's opinion, Gervase's martyrdom in April changed the whole complexion of events, allowing Beech to prove the worth of the Douai "novitiate" to both the Vatican and Spain. ${ }^{52}$ It was against this backdrop of transnational dispute that Worthington made his claim on Gervase's martyrdom.

Anselm Beech, the Benedictines' representative in Rome, was in no doubt about the motives behind the false appropriation of Gervase. Alluding to the recent martyrdom in a report to the pope in 1608, Beech declared: "Our opponents seek to drive us from the establishment at Douay: they covet a monopoly of that mission, in which our substance and our blood have been expended."53 In another memorial that same year, Beech warned Pope Paul V that Robert Persons, the Jesuits, and their supporters (such as Worthington) sought domination of the English mission. He charged that members of the Society made great accusations against both secular and regular clergy, even against those who had been martyred. With evident reference to the Gervase saga, Beech railed, "If they cannot deny that they are religious, they deny that they are martyrs, as in Japan; if they cannot deny the martyrdom, they deny that they are monks, as now they do in the case of a monk of our own who was martyred in England, and whom they are not willing to admit that he was a monk." 54 Writing on 10 January 1609, Guido Bentivoglio, the nuncio in Brussels, considered the two conflicting images of Gervase as a pointed manifestation of the tensions between the college and the monks in Douai; like Beech, he suspected the dead hand of the Jesuits and their allies. ${ }^{55}$

Nor was Worthington coy about linking the Gervase saga to the Douai battle. Apparently still smarting about the affair as late as 1614, he prefaced a new edition of his Catalogus Martyrum with a brief introduction on the origins of the various missions to England. He stated that Gregory Sayer left the English College at Rome as a priest around 1588 and entered the Benedictines, followed by Anselm Beech and others. Worthington then noted that the same happened in

${ }^{51}$ Letter copied by Grene. ABSI, cause papers, George Gervase picture file.

52 David Lunn, The English Benedictines, 1540-1688: From Reformation to Revolution (London, 1980), $72-73,77,79-81$.

${ }^{53}$ Tierney, Dodd's Church History, 4:88n2 (at 89).

${ }^{54}$ Ibid., 4:ccxvi (author's summary translation from the original Italian; direct quoted translation from Camm, Nine Martyr Monks, 98).

${ }^{55}$ Lettere di Monsig[nore] Bentivolgio, fols. 364r-366r, 207, Archivio Segreto Vaticano, Nunziature Diverse. 
1599, this time with students from the English College at Valladolid entering the Benedictines. These new monks were subsequently sent to England, their numbers swelled by monks from Italian monasteries and men whom the Benedictines enrolled as oblates in England. Having established that, in his view, the Benedictines acted parasitically toward the colleges, Worthington delivered the final blow: some, he claimed, returned from England and started to live in Lotharingia "and set up a convent," Saint Laurence's in Dieulouard, "partly assembled from England but especially from English seminaries, not only students but also some priests." 56 Without explicitly mentioning the Douai episode, Worthington thus made it clear that the Benedictines had a history of poaching college students like Gervase. Notably, whereas the first (1608) edition of Worthington's work had been in English, the 1614 edition, which included this only partially controlled version of events, was in Latin-suggesting, as Thomas McCoog has argued, that the book was aimed at a wider European market rather than just English Catholics. ${ }^{57}$ In other words, this anti-Benedictine message was what he wanted to convey to Catholic Europe and its potential benefactors and patrons. His pamphlet depicting Gervase as a secular priest of Douai was again in Latin, also evidently designed for consumption in mainland Europe.

\section{THE OATH OF ALLEGIANCE AND EUROPEAN PATRONAGE}

Gervase's martyrdom related to English matters and also rested on an issue then the topic of Europe-wide debate. In England, martyrs and their legacies had previously featured in national debates, whether in relation to the religious politics of the state church, the state's laws in support of order, or intra-Catholic debates about how to interact with those same laws. ${ }^{58}$ Equally, English Catholics who died for their faith loomed large in the Tridentine consciousness of Catholic Europe. English martyrs were paralleled to the martyrs of the early church following the then recent discovery of the catacombs in Rome. The plight of English Catholics became both a rallying point against Protestant reform and a cause célèbre for promoters of the Catholic Reformation. ${ }^{59}$

${ }^{56}$ Worthington, Catalogus Martyrum, 8-9.

57 Thomas M. McCoog, "Construing Martyrdom in the English Catholic Community, 1582-1602," in Catholics and the "Protestant Nation": Religious Politics and Identity in Early Modern England, ed. Ethan Shagan (Manchester, 2005), 95-127, at 105-6.

${ }^{58}$ See, for example, Peter Lake, "A Tale of Two Episcopal Surveys: The Strange Fates of Edmund Grindal and Cuthbert Mayne Revisited," Transactions of the Royal Historical Society 18 (2008): 129-63; Thomas S. Freeman, "Fate, Faction, and Fiction in Foxe's Book of Martyrs," Historical Journal 43, no. 3 (September 2000): 601-23; Karl Gunther, "The Marian Persecution and Early Elizabethan Protestants: Persecutors, Apostates, and the Wages of Sin," Archiv für Reformationsgeschichte - Archive for Reformation History 107, no. 1 (October 2016): 137-64; Peter Lake and Michael C. Questier, "Puritans, Papists and the 'Public Sphere' in Early Modern England: The Edmund Campion Affair in Context," Journal of Modern History 72, no. 3 (September 2000): 587-627; Lake and Questier, "Margaret Clitherow, Catholic Nonconformity, Martyrology and the Politics of Religious Change in Elizabethan England," Past and Present 185, no. 1 (November 2004): 43-90; Lake and Questier, The Trials of Margaret Clitherow: Persecution, Martyrdom and the Politics of Sanctity in Elizabethan England (London, 2011).

${ }^{59}$ See, for example, Brad S. Gregory, Salvation at Stake: Christian Martyrdom in Early Modern Europe (Cambridge, MA, 1999). 
Gervase was more than just a martyr; his death concerned the European touchstone issue of the day. The Oath of Allegiance of 1606 had been drawn up in the wake of the Gunpowder Plot. Its purpose, and the diligence with which it was administered, have been the subject of intense historiographical debate. Michael Questier has argued that, rather than merely a means to root out Catholic extremists, the oath went beyond a simple rejection of the papal deposing power, which its authors knew was a matter of debate among Catholics. It also included a deliberate theological accusation of heresy against Rome, which could be ultimately interpreted as "a rejection of the papal primacy." The oath thus blurred the division between politics and religion, loyalty to the monarch, and allegiance to the Church of England, and so eroded the boundaries of English Catholic self-identity. Far from "a simple profession of civil allegiance," it was "an exceedingly complex association of religious and political ideas, a diabolically polemical cocktail” designed to destroy English Catholic resistance. ${ }^{60}$ In contrast, Johann Sommerville has argued that the architects of the oath, Archbishop of Canterbury Richard Bancroft and James I, were seeking guarantees against Catholic political violence like that attempted at the Gunpowder Plot. Sommerville ventures that Catholics refused that path not because of some heretical clause that granted James I theological authority but because the papal deposing power was an unassailable part of the faith. In other words, the oath was designed to do exactly what James claimed-to sort traitorous Catholics from loyal. ${ }^{61}$ In response, Questier has maintained that the oath was administered to known moderates and at certain points was proffered with increased regularity against recalcitrant Catholics. As such, it was never about exposing genuine traitors; rather, the aim was to secure more than just outward obedience from Catholics. ${ }^{62}$ In the opinion of Stefania Tutino, the oath was designed to separate loyal and traitorous Catholics, thus acting as a "politico-theological weapon" not limited to attacking papal authority; it actually granted the sovereign a form of spiritual, as well as temporal, power. ${ }^{63}$

All reports of Gervase's trial and death concur that he strongly refuted the Oath of Allegiance and proclaimed not just the pope's spiritual authority but also his temporal power. Charnock recorded that Gervase refused to take the oath on several occasions. When asked whether the pope could excommunicate or depose princes, Gervase answered, "Yea and allso all Kings in the world." 64 Charnock repeated Gervase's words at Tyburn: "[']I am herther brought to suffer death for beeing a priest, and for refussing to take an unlawfull oath,['] to which the Sheriff once demanded whether he would yet take it, unto which he answered no but willingly would take

\footnotetext{
${ }^{60}$ Michael C. Questier, "Loyalty, Religion and State Power in Early Modern England: English Romanism and the Jacobean Oath of Allegiance," Historical Journal 40, no. 2 (June 1997): 211-29.

${ }^{61}$ Johann P. Somerville, "Papalist Political Thought and the Controversy over the Jacobean Oath of Allegiance," in Catholics and the "Protestant Nation": Religious Politics and Identity in Early Modern England, ed. Ethan Shagan (Manchester, 2005), 162-84.

${ }^{62}$ Michael Questier, "Catholic Loyalism in Early Stuart England," English Historical Review 123, no. 504 (October 2008): 1132-65, esp. 1136-44.

${ }^{63}$ Stefania Tutino, Law and Conscience: Catholicism in Early Modern England, 1570-1625 (Aldershot, 2007), 117-93; Stefania Tutino, Empire of Souls: Robert Bellarmine and the Christian Commonwealth (Oxford, 2010), 128.

${ }^{64}$ Account of the martyrdom of George Gervase, AVIII, no. 52: 287-89, WDA.
} 
any oath not prejudising his concience or the Catholike faith." 65 For Charnock, Gervase's death was unequivocally caused by his refusal to take the recently introduced oath, his trial and prosecution representing something of a test case for its reception. The additional hand on the manuscript supports this view. It notes that, when asked by the authorities if the pope could depose princes, Gervase requested that they not ask this as it was a "bloody question," before affirming that the Pope could do so. ${ }^{66}$ Writing to Robert Persons, S.J., from London on 15 April 1608, the superior of the Society in England, Richard Holtby, was in no doubt that Gervase was "arraigned and condemned ... because he refused to take the oath, and withal cleerly confessed $\mathrm{y}^{\mathrm{t}}$ the Pope had authority to depose any king in christendome, if he desired it." $\mathrm{He}$ added that Gervase "refused the oath most constantly." 67 Luisa de Carvajal related Gervase's stand against the oath to several of her correspondents in mainland Europe. She compared it favorably to the backsliding examples of the likes of the archpriest Blackwell, who had submitted to the oath to save his life. ${ }^{68}$

The oath, therefore, was a further factor behind the competing claims for Gervase's martyrdom. In April 1608, the diary of Douai College, then under Worthington's leadership, recorded Gervase's death for his being a priest and his refusal to take the oath. Supporting Questier's claim that the oath was administered as a form of repression, the diary - maintained as a chronicle of college life rather than for publication - stated that it was "exacted from all Catholics, especially from priests and the richer lay-folk." Contrary to Somerville's claim that Catholics were not particularly interested in the theological dimensions of the oath, the diary observes that the oath "denies the power" of the pope "to depose secular sovereigns on account of heresy, and to deprive them of their temporal sovereignty for any reason whatever."69 In other words, those at Douai fully recognized the oath's implications and what was at stake. (Tellingly, the diary did not mention that, at the time of his death for taking a stand against the oath, Gervase was in fact a Benedictine.)

As Thomas McCoog has asserted, "no weapon was too dirty" in England's intraCatholic disputes. By the opening years of the seventeenth century, martyrs had become part of this dirty war. In the case of the Archpriest Controversy, McCoog judges that interest in the English martyrs remained "ideologically driven," meaning the persecution was exploited to establish pedigree and to advance a particular approach to the English mission. ${ }^{70}$ This is exactly what the Benedictines sought

65 Ibid.

${ }^{66}$ Ibid. Gervase's desperation to evade answering the question supports Questier's view that Catholics were deeply troubled by the carefully chosen words of the oath and were eager to avoid its implications. Questier, "Catholic Loyalism," 1132-65.

${ }^{67}$ Richard Holtby to Robert Persons, 15 April 1608. Richard Smith would later attest to Gervase's opposition to the oath: A IX, no. 53: 291-92, WDA.

${ }^{68}$ Redworth, Letters, 1:301-4, 2:1-4, 12, 14, 21-22, 24-25, 34-35, 46-47. The author of the third Douai diary alluded to these conflicts when writing up the death of Gervase, noting how some priests who took the oath were spared. Burton and Williams, Donay College Diaries, 90, 351. Indeed, at his trial, Blackwell's acceptance of the oath and his view that to refuse it was to die a traitor rather than a martyr was dangled before Gervase. TNA, Roman Transcripts (Bliss), 23 April 1608, translation from Italian in Camm, Nine Martyr Monks, 90.

${ }^{69}$ Burton and Williams, Doway College Diaries, 90, 351.

${ }^{70} \mathrm{McCoog}$, "Construing Martyrdom," 120. McCoog places Worthington’s English language 1608 publication of his A Relation of Sixtene Martyrs in this context and views it as an attempt to support Robert Persons and the Jesuits against the claims of a faction of the secular clergy. Ibid., 112-19. Questier 
to do with Gervase's death and why it was so important to them, just as it was vital to Worthington that he preserve the established narrative of Douai College primacy. As Anne Dillon has noted, the phenomenon of martyrs becoming an unseemly point of division originated at the end of Elizabeth's reign, ${ }^{71}$ but it was only now that an official state initiative - the oath — directly affected these debates and brought them out into wider circulation, as witnessed by the two Gervase pamphlets. Questier is therefore correct in his assertion that the oath was "possibly the most lethal measure against Romish dissent ever to reach the statute book." It threatened the very existence of English Catholicism, fracturing its "ideological unity into an uncontrollable variety of opinion." In other words, it caused "chaos and division," splitting apart all clerical groups, including the Benedictines. ${ }^{72}$ The Venetian ambassador to England, Zorzi Giustinian, judged as much, writing to the Doge and Senate on 23 April 1608, two days after Gervase's execution, that the papal brief issued against the oath "begins to breed those ill effects for the Catholics which were very clearly foreseen." He expressed his view that Gervase would normally have been reprieved if it was not for the papal brief, which ultimately provoked English authorities into presenting the condemned man with the oath. The ambassador added, "The results of the brief will not stop there; it will breed still wider injury to the Catholics, for it has aroused an open division and schism among them." 73

However, the impact of the oath and the papal ruling against it was not only a matter of domestic concern. As Tutino has evinced, the Oath of Allegiance was a pan-European issue with wide repercussions for the reach of papal power within fledgling nation states. She suggests that James I placed himself in the text of the oath "as one interpreter of scripture fighting with another over the nature and scope of temporal authority." Thus, what was ostensibly an English Catholic situation-specific political act was also a theological statement on "the pan-European politico-theological issue of the relationship between political and religious authority." Both James I and the church, through the Jesuits Robert Persons and Robert Bellarmine, recognized that the oath could set a precedent for other European countries, Protestant or Catholic. As such, the monarch dedicated his defense of the oath, A Premonition to All Christian Princes ..., to all the sovereigns of Europe, irrespective of their denominational allegiance. Moreover, he had his ambassadors present the work at the courts of Europe. It caused a particular stir in Venice and France, not to mention in the German context, as European monarchs sought to "enforce an

\footnotetext{
has posited that martyrs and their beliefs or stands could be appropriated for different purposes, such as the anti-Jesuit gloss put on Thomas More by a section of the secular clergy in the early seventeenth century; see Questier, "Catholicism, Kinship and the Public Memory of Sir Thomas More," Journal of Ecclesiastical History 53, no. 3 (July 2002): 476-509.

${ }^{71}$ Anne Dillon, The Construction of Martyrdom in the English Catholic Community, 1535-1603 (Aldershot, 2002), 326.

${ }^{72}$ Questier, "Loyalty, Religion and State Power," 313-17.

73 "Venice: April 1608," in Calendar of State Papers Relating to English Affairs in the Archives of Venice, vol. 11, 1607-1610, ed. Horatio F. Brown (London, 1904), British History Online, http://www.britishhistory.ac.uk/cal-state-papers/venice/voll1/ppl14-129, accessed 31 March 2017, 114-29.
} 
increasingly sacralised view of their sovereignty against the universalistic pretence of the pope. ${ }^{.74}$

In this international context, the English Benedictines spotted an opportunity to pose as the Oath of Allegiance's most steadfast opponents. In the argument with Worthington about their establishment at Douai, the monks quickly recognized the potential of a martyr who had stood resolutely against the oath. In a letter of 2 August 1608 from Rome, Fitzherbert cattily observed to Worthington that the Benedictines "have prevayled theym selves greatly of that martirdome, as the popes secretary told me a few dayes ago."75 Fitzherbert was well informed; on 24 May 1608, Guido Bentivoglio, the nuncio in Brussels, had written to Pope Paul V that the monks from Douai had been to see him about "George Gervase of their order," who had been executed in England. Underlining how this promotion of Gervase was linked to a wider agenda, Bentivoglio explained that the monks had insisted strenuously that "they live here in Flanders following the rule of good and faithful religious entirely devoted to preserving and advancing the Catholic faith." As such, the monks argued, this demonstrated the falsity of the allegations against them. Bentivoglio finished by saying that the monks had asked him to represent their cause to the pope. ${ }^{76}$

The English Catholic landscape had been reshaped by the arrival of the Benedictines and, on an international level, they had to justify their missionary endeavors to the official church. In 1608, the monks' representative in Rome, Anselm Beech, drew up a paper for the pope to counter accusations made against the fledgling English Benedictine movement. One claim was that the monks were suspect on the question of the Oath of Allegiance, as demonstrated by the writings in its favor by one of their number, Thomas Preston. ${ }^{77}$ Beech maintained that even before the Apostolic brief condemning the oath, all Benedictines had denounced it as an "intrinsic evil," pointing to the fact that one had "suffered death" for withstanding it, as had "a confrater of the Order" and "another monk." These three are identifiable respectively as Gervase, Drury, and John Roberts. Beech added that all the remaining monks agreed with the martyrs' position and that "they preferred to die unsworn rather than live."78 The importance placed on the witness of Gervase and his confreres was underlined on the deed of acceptance for Saint Gregory's foundation at Douai, on which images of the missionary martyrs were used to flank the text.

The international debate over the oath also offered the English Benedictines an opportunity to align themselves for the receipt of patronage. Spain, the Catholic superpower of the early seventeenth century, played a vital role as financier of the

\footnotetext{
${ }^{74}$ Tutino, Empire of Souls, 127-211, at 129, 130, 158; On Temporal and Spiritual Authority: On Laymen or Secular People; on the Temporal Power of the Pope, against William Barclay; On the Primary Duty of the Supreme Pontiff, by Robert Bellarmine, ed. and trans. Stefania Tutinio (Indianapolis, 2012), xvi-xiv, 121405. On the impact in France, see also Questier, "Catholic Loyalism," 1151-52.

${ }^{75}$ Hicks, Letters of Thomas Fitzherbert, 25.

${ }^{76}$ TNA, Roman Transcripts 9, bundle 116, printed in ibid., 25-26. My thanks to Stefano Cracolici for his translation from the original Italian.

77 Stefania Tutino, "Thomas Preston and English Catholic Loyalism: Elements of an International Affair," Sixteenth Century Journal 41, no. 1 (Spring 2010): 91-109.

78 Tierney, Dodd's Church History, 4:ccxiii (author's translation from the Latin).
} 
English Catholic enterprise within the wider Catholic Reformation. ${ }^{79}$ The English College at Douai, for example, relied on Spanish financial support. Tellingly, in November 1609, Worthington revealed to the archpriest Birkhead that the Spanish crown's alms were unpaid for the previous five years, leaving a significant hole in the accounts of three thousand pounds sterling. ${ }^{80}$ Worthington hastened to add that this was due to administrative errors on the Spanish side, but it cannot have escaped his notice that a martyr who stood so firmly against the oath would be an eye-catching reminder to papalist Spain of their duties to the English College. Worthington's claim on Gervase for Douai was thus a direct appeal to Spanish support. Meanwhile, in November 1604, members of the Spanish governing class had expressed their anxiety to Phillip III about an English Benedictine mission because of "the danger of rivalry and divisions" and concern that the timing might not be "advantageous" for relations with James I. ${ }^{81}$ There had been "considerable opposition" in Spain and Italy to the mission's launch, suspicions aroused that the Benedictines would take recruits from the exile colleges and provoke further divisions in the English mission, and that such an undertaking was in "direct violation of the monastic vow." 82 However, the martyrdom of Benedictines on the English mission, including that of Gervase, shifted perceptions of the enterprise from unease to high esteem, as Clement Reyner recognized, writing in the 1620s. ${ }^{83}$ Similarly, it eased concerns harbored by Spanish Benedictines such as Antonio de Yepes, who, in the light of Gervase's death, wrote in 1613 of the suitability of missionary work for English monks. ${ }^{84}$

Moreover, in the Benedictines' efforts to secure Spanish favor, Gervase's stand against the oath bore immediate fruit. Writing to Phillip III from London on 21 April 1608, the Spanish envoy to England, Pedro de Zúñiga, placed Gervase's martyrdom squarely in the context of the Oath of Allegiance. He heaped scorn upon "feeble" and "despicable" priests like Blackwell who took the oath and whose position de Zúñiga was certain the authorities were willing to exploit. After unsuccessfully attempting to cajole the Jesuit Thomas Garnet to take the oath, wrote de Zúñiga, the authorities turned to Gervase, "trusting him to be timid" and "of less progress in learning," and so they expected to be able to "lead him about as they might want." Instead, "the saintly monk" was "so firm in his stirrup that he told them he did not take the oath because it was heretical," even though his loyalty to the king was as firm as any other subject's. When asked if the pope could excommunicate and depose the king, Gervase did not flinch, replying he could, and that it was "permissible for his subjects to take up arms.” De Zúñiga stated that Gervase died "with the same intrepidity" declaring that "such unabashed truths and deep constancy have not been heard before from anyone." Even at the moment of his hanging, Gervase refused to yield, maintaining that since "the brief had come

\footnotetext{
79 See, for example, Thomas M. McCoog, The Society of Jesus in Ireland, Scotland, and England, 15891597: Building the Faith of Saint Peter upon the King of Spain's Monarchy (Farnham, 2012).

80 Tierney, Dodd's Church History, 5 :civ-cvi.

${ }^{81}$ The Constable of Castille to Phillip III, 22 November 1604, Manuscritos Varios, tomo 6969, fols. 115-25, Madrid, Biblioteca Nacional; printed in Loomie, Spain and the Jacobean Catholics, 26-44, at 39.

${ }^{82}$ Tierney, Dodd's Church History, 4:87nl (at 88).

${ }^{83}$ Reyner, Apostalatus Benedictinorum in Anglia, Tract 1, 247.

${ }^{84}$ Camm, Nine Martyr Monks, 101-2.
} 


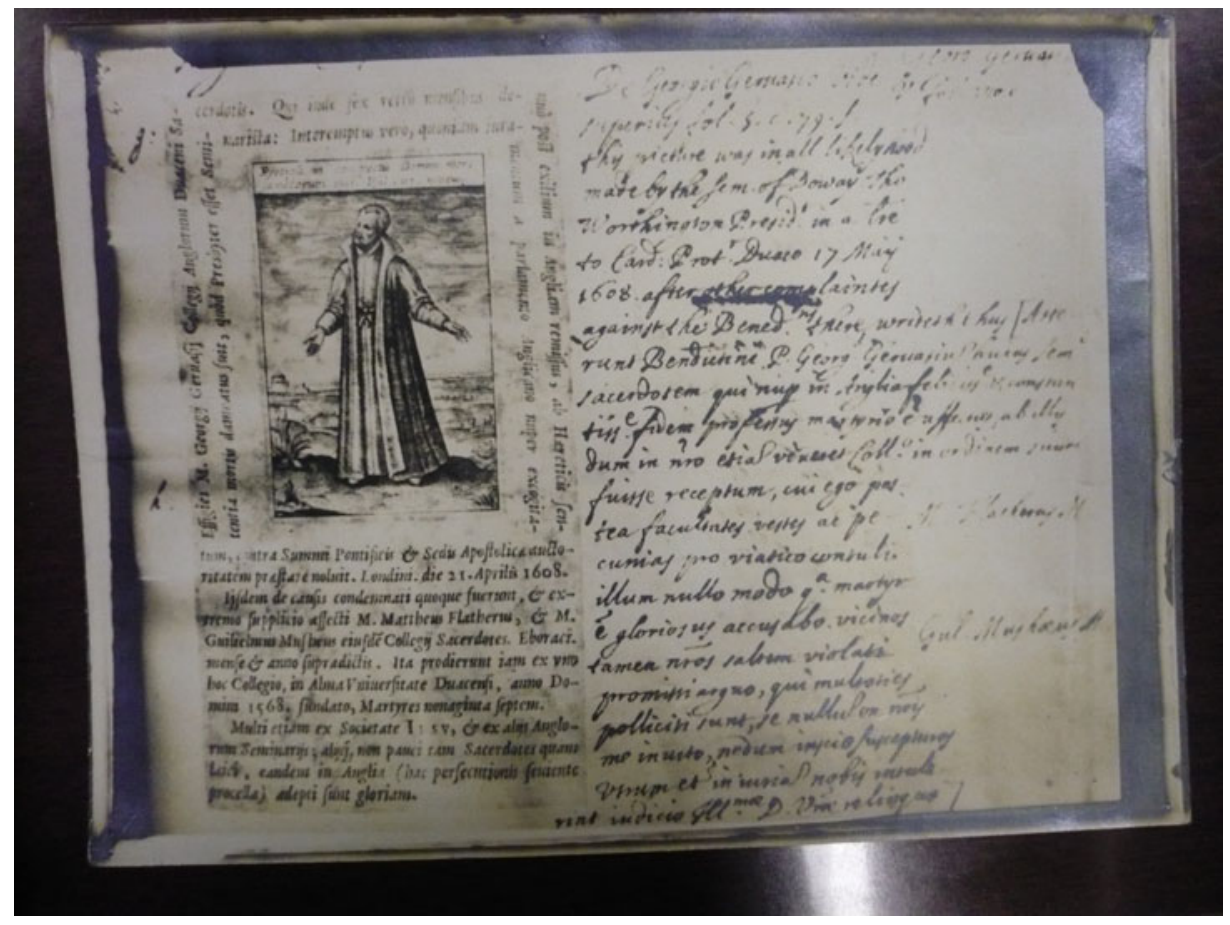

Figure 1-George Gervase depicted as a secular cleric. Archivum Britannicum Societatis Iesu, cause papers, George Gervase picture file.

from his Holiness the door remained closed to taking the oath.” De Zúñiga finished by saying he expected many would follow Gervase's stand and believed that the Privy Council would have to adapt its approach "because there is a great number of people to hang." 85

As de Zúñiga's comments attest, anyone seeking support from papalist Catholic powers and the pope himself stood firmly against the oath. That is why the English Benedictines rushed to circulate accounts of Gervase's martyrdom throughout mainland Europe and emphasized his unequivocal support for the pope's temporal and spiritual authority. It is why Worthington did the same: his determination to claim Gervase as a martyr against the oath was stoked by his need to secure further Spanish support for Douai College, then mired in financial difficulties. It also, therefore, explains why the English Benedictines, according to Fitzherbert, acted with such fury at attempts to hijack "their" martyr. Gervase's stand against the oath earned the monks the international prestige they needed to justify their mission to a potentially unconvinced post-Council of Trent Europe, particularly Spain, in which monastics, male as well as female, were supposed to be fully enclosed.

${ }^{85}$ Loomie, Spain and the Jacobean Catholics, 117-19. De Zúñiga repeated this version of events in a letter of the same day to Don Alonso de la Cueva y Benavides, Spanish ambassador to the Republic of Venice. See Vat.lat.6227, fols. 207r-208r, 213r-214v, Vatican Library. 


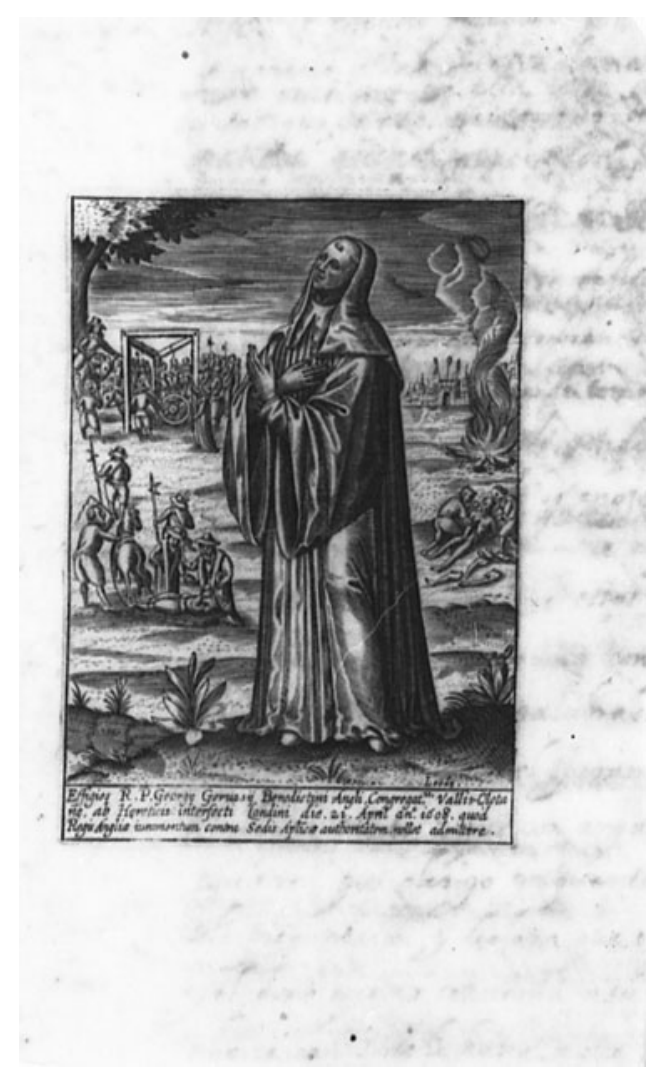

Figure 2-George Gervase depicted as a Benedictine monk. "Varia de Rebus Angliae super successione ad Regnum variae relationes ab anno 1597 usq. ad 1608," Vatican Library, Vat.lat.6227, fol. 212rbis.

Crucially, Gervase's martyrdom helped the English Benedictines to mobilize international support, attracting the patronage of certain benefactors, especially Spain, and this ultimately helped shape the religio-political identity of the English Benedictine movement. The stand against the oath of those monks linked to Spain-like Gervase and his fellow Benedictine martyrs, John Roberts and Maurus Scott (d.1612) $)^{86}$ - meant they prevailed against the numerically smaller, Gallican-inclined Cassinese vision for the English Benedictines. In short, the English Benedictines came to be characterized as siding with the papalist vision of English Catholicism rather than the Gallican. From initially showing signs of siding with the Appellants, they became instead associated with the more rigorous Jesuit wing of English Catholicism. ${ }^{87}$ It is for this reason that the English Benedictine Congregation,

${ }^{86}$ For Roberts and Scott, see ID 698, 699, Monks in Motion, www.dur.ac.uk/mim, accessed 25 October 2017.

${ }^{87}$ Although this argument accords with Lunn's, it does question his assertion that the monks initially favored the oath simply because of anti-Jesuit sentiment. The existence of the conflicting images instead 
formed when the Anglo-Spanish and Westminster monks agreed on their terms of union in 1617, opened its new constitutions with an unequivocal statement against the oath, forbidding any monk from supporting its content. ${ }^{88}$ It is also why Thomas Preston and his pro-oath opinion became such an embarrassment to those papalists increasingly gaining control of the English Benedictine movement. ${ }^{89}$ With a martyr for papal authority against the Oath of Allegiance, the English Benedictines were playing to a European audience that Worthington and his supporters feared losing. The contested claims for Gervase the martyr were not just a domestic matter on the peripheries of Catholic Europe but were expressions of vital issues pertinent to Catholic reform being voiced at the continent's center.

bears testament to the more fundamental importance of international influence and reputation from the very start of debates about the oath. Maurus Lunn, "English Benedictines and the Oath of Allegiance, 1606-1647," Recusant History 10, no. 3 (October 1969): 146-63.

88 "It is our will, that this Union be not agreed upon in any other manner than that all and every one of such as are to be united, do conform themselves to the doctrine of the Holy Roman Church; as well generally in all matters that concern either belief or manners, as specially and in particular, in accepting and submitting to the Decrees of our Holy Father Pope Paul V touching the oath of allegiance, and authority and jurisdiction of the Church and holy Apostolic See. But with others (if there be any such) who dissent from those articles or Decrees, we do by no means intend to strike up an Union or hold communion, unless within six months after a sufficient admonition thereof by their Superiors, they purge themselves from such imputation and give sufficient satisfaction to the said Superiors of this Congregation." Bennet Weldon, Chronological Notes, Containing the Rise, Growth and Present State of the English Congregation of the Order of St. Benedict (London, 1881), 109.

${ }^{89}$ For Preston and his Gallicanism, see Maurus Lunn, "The Anglo-Gallicanism of Dom Thomas Preston, 1567-1647," in Schism, Heresy and Religious Protest, ed. Derek Baker (Cambridge, 1972), $239-46$. 